\title{
'A DISTINCT DEGREE IN COMMERCE': CHARLES HUBERT OLDHAM AND THE ESTABLISHMENT OF UNIVERSITY-LEVEL COMMERCE EDUCATION IN IRELAND
}

\author{
Peter Clarke \\ University College Dublin \\ Ciarán Ó hÓgartaigh \\ University College Dublin \\ and \\ Margaret Ó hÓgartaigh \\ All Hallows College, Dublin City University
}

\begin{abstract}
$\mathrm{T}$

There is a limited prior literature on the development of accounting and business education in third-level institutions in Ireland. This paper attempts to partly fill this vacuum by focusing on Professor Charles Hubert Oldham, who, in 1909, became the first professor of Commerce in the newly created University College Dublin. He was appointed the first dean of the faculty the following year and remained in this position until his sudden death in 1926. A Home Rule Protestant, Oldham was prominent in the Irish 'urban intelligentsia' from 1882 until his death in 1926, a period of significant political and social change in Ireland. This paper provides a greater understanding of his contribution to education and his context as an educator.
\end{abstract}

\section{INTRODUCTION}

I greatly prefer a distinct degree in Commerce, for if you consider you have pioneer work to do, if you create a distinct degree in Commerce, it will be a decided help towards the object aimed at. Make the qualification as high as possible, but have a distinct degree (Charles Hubert Oldham in evidence to the Dublin Commission, 1909, p. 72).

Charles Hubert Oldham (1859-1926) was an 'important influence' (Foster, 1997, p. 47) and 'prime mover' ${ }^{1}$ in cultural and political circles in late nineteenth century 
Clarke, Ó hÓgartaigh and Ó hÓgartaigh

Dublin. He was one of the founders of the Dublin University Review, which first published the poetry of W.B. Yeats, and founder and host of the Contemporary Club, whose regular participants included Yeats, Maud Gonne, Douglas Hyde and Arthur Griffith. In 1901, he was appointed the first principal of the Rathmines School of Commerce (which subsequently became part of the Dublin Institute of Technology). ${ }^{2}$ In 1909, he became the first professor of Commerce at the newly established University College Dublin (UCD) and, from 1910, was its first dean of Commerce.

This paper sets out and analyses the contribution of Oldham to the development of university business education in Ireland in the early twentieth century. Anderson-Gough $(2008$, p. 297) writes that 'education is not a subject area yet chosen for significant study by accounting historians'. This paper contributes to Irish accounting and business history by tracing the contribution of Oldham from his days as a '25-year-old Trinity star' (Foster, 1997, p. 39) through to his time as the first professor of Commerce at UCD.

There is no official publication detailing the history of the UCD Faculty of Commerce. The official history of UCD (McCartney, 1999), while lengthy, scarcely mentions the Faculty of Commerce. Clarke (2005) discussed the life of the late Professor Bernard Shields (dean from 1927 to 1951), who became the holder of the first chair in a United Kingdom (UK) university with 'Accounting' or 'Accountancy' in its title when he was appointed as Professor of Commerce and Accountancy at University College Galway in 1914. The considerable contribution of the late Professor George O'Brien (dean of UCD's Faculty of Commerce from 1951 to 1961) has been elegantly covered by Meenan (1980) and James Meenan's own significant achievements (dean from 1961 to 1973) have been outlined by Lysaght (2005). However, Oldham's contribution to the early development of commerce education in UCD and more widely has not yet been discussed.

This paper adds to our understanding of the development of business education at third level in Ireland by reviewing the archival material relating to Oldham, together with his considerable publications and writings about him by others. These are discussed with reference to the evolving political and educational context during the final decades of the nineteenth century and the early years of the twentieth century.

The paper is divided into three main sections. The next section outlines Oldham's background and his contribution to the cultural and political context of late nineteenth century Dublin. The following section then discusses his role, through submissions to the Dublin Commission, in shaping the establishment of the National University of Ireland and its constituent colleges in 1909. The third section discusses Oldham's contribution to UCD and the wider community until his sudden death in 1926.

\section{THE BACKGROUND OF CHARLES HUBERT OLDHAM}

In his application to King's Inns in 1888 and for the professorship of Commerce at UCD in 1909, Oldham states that he was born in 1859. He was a twin but his sister, Cecily, died as a young child after a severe attack of scarlet fever - a fever common 
in children between five and fifteen years of age at that time. Charles Oldham was the eighth child in a family of twelve, of which four died young (Ferguson, 2009).

Oldham's 1888 memorial to King's Inns and his 1909 application to UCD for the professorship of Commerce provide some personal background. He was the youngest son of Mr Eldred Oldham, silk merchant, of 11/12 Westmoreland Street, Dublin and Anne Oldham (née Alker), daughter of a house furnisher (McGee, 2009). He received his secondary education at Kingstown Grammar School, Dún Laoghaire, where he spent eight years 'under a remarkable staff of teachers, five of whom became eventually University professors' (Oldham, 1909), and he was subsequently educated at Trinity College Dublin (TCD), where he won a foundation scholarship in mathematics in his junior freshman year. He obtained first class honours in both mathematical and experimental science subjects at every examination of his degree, graduating in 1882 with a double honours degree, having achieved a gold medal in both mathematics and experimental science (i.e. physics and chemistry) (Trinity College, 1951). He remained in residence in TCD for some three years after he graduated (c. 1882-1885) and describes his work as 'grinding pupils in the subjects of my Honour Degrees, and I had a large experience as a teacher' (Oldham, 1909).

He also tutored in Strangway's, a private day school at 98 St Stephen's Green South run by Leonard R. Strangway (Thom's Directory, 1884). In Strangway's, Oldham taught for three hours per day and two on Saturday, for $£ 120$ per annum (Ferguson, 2009). Letters from his mother to his sister Edith in London, where she studied at the Royal College of Music, indicate that money was very scarce around that time in the Oldham household. Oldham provided financial support to his sister, and his mother writes 'Hubert would not allow you to want for absolute necessities [and] only what is absolutely necessary must be taken from him' (Oldham, A., 7 December 1883). His mother subsequently wrote that Charles' political opinions caused Strangway's to give him notice and that his 'pronounced opinions as a politician have seriously injured his prospects as a teacher' (Oldham, A., 12 July 1886), and that these opinions have 'left him without friends or income' (Oldham, A., 30 August 1886). He became editor of a new paper, North and South, at a salary of $£ 2-10-0$ per week (Oldham, A., 31 December 1886). For reasons that are not clear from the available archival material, it appears that he did not get on well with Webb - the owner - and Oldham received two months' notice to give up the editorship (Oldham, A., 22 April 1887).

In February 1885, Oldham, with T.R. Rolleston, established the Dublin University Review, the only monthly magazine published in Ireland at that time - it also circulated in England. Oldham became its managing director for three years (Oldham, 1909). The first edition of the Review indicates that a limited company was established to facilitate its publication, which would limit 'the liability of those who have subscribed the capital necessary to start it [and] in no case can any member become liable for more than the amount still remaining unpaid on the shares standing in his name', and it was also indicated that an additional $£ 300$ was to be raised (Dublin University Review, 1885, inside cover). The Review's contributors were wellknown personalities who played a significant role in Irish political and cultural affairs around that time, including Douglas Hyde, Samuel Ferguson and Michael Davitt. An insert in the November 1885 edition announced a change of offices and 
Clarke, Ó hÓgartaigh and Ó hÓgartaigh

the relocation of Oldham to 'new chambers' at 116 Grafton Street; and his residence, according to various editions of Thom's Directory, continued at this address for many years thereafter.

Oldham left TCD - both as a tutor and from his lodgings there - around 1885. Chaudhry (2001) suggests that he was dismissed from his teaching post after publishing an article in the Dublin University Review by Michael Davitt (Davitt, 1885), the Irish nationalist and founder of an agrarian activist movement, the Land League, in September 1885. Foster comments (1997, pp. 39-40) that UCD (where he later became Professor of Commerce) was 'more hospitable' to Oldham's Home Rule politics than TCD.

Soon after Oldham's dismissal from TCD, he founded the Contemporary Club, which met weekly to debate any subject of interest to the members; the characteristic of the Club was its freedom of thought and expression (see Nicholls, 1965a; 1965b). The Contemporary Club was a setting where current political issues were argued out not only between nationalists and unionists, but also among nationalists themselves: between advocates of constitutional methods such as Oldham and champions of physical force like the Fenian John O'Leary (Daly, 1974). Those attending included political and literary figures such as Douglas Hyde, founder of the Gaelic League and later President of Ireland (1938-1945), Arthur Griffith, ${ }^{3}$ the founder of Sinn Féin, Maud Gonne and W.B Yeats.

Oldham was involved in many other activities. He was a council member of the National Literary Society, and his UCD colleague Professor Mary Macken was also a member of the society (Irish Times, 16 and 18 June 1913). In addition, Oldham was a member and officer of the United Irish League with UCD colleague Professor Tom Kettle (Irish Times, 29 January 1913). The United Irish League was a nationalist political party organised around a programme of agrarian agitation, political reform and Home Rule, and by 1901 it claimed 100,000 members (Hickey and Doherty, 1980).

In 1888, describing himself as a 'college teacher', Oldham registered as a student of King's Inns (Ferguson, 2005). This registration required a payment of $£ 25$. It is possible that Oldham was influenced in his choice of study by the repeal of legislation in 1885 that required students reading for the Irish Bar to 'reside' for a specified number of years at one or other of the inns of court in London (Ferguson, 2005). With the repeal of this legislation, qualification for the Irish Bar was less expensive and did not require residency abroad. In 1890, Oldham qualified as a barrister-at-law and his King's Inns memorial further indicates that he attended a variety of lectures during his years of study and that he passed the examinations with honours. These exams included, for example, law of personal property, feudal and English law, and equity law; these disciplines provided him with the ability to subsequently teach various law subjects (King's Inns, undated). In addition, he obtained a Brooke Law prize in his final exam in the amount of $£ 21$ and he was called to the Bar in November (Irish Law Times, 1890). Subsequently, Oldham is listed as a barrister (Thom's Directory, 1894; Ferguson, 2005) who practiced on the north-western circuit with about 50 other barristers.

Oldham's obituary indicated that his political activities were responsible for the decline in his law practice and the 'severance of his career with the legal profession' (Irish Times, 22 February 1926). In his own words in his application to UCD 
(Oldham, 1909), 'he travelled the North West Circuit for some years [but] Barrister's work was never quite congenial to me, and since 1895 I have not pursued the profession'. Thom's 1897 Directory lists Oldham as a mathematical and science teacher and residing at 116 Grafton Street.

In 1895 Oldham was appointed a Barrington Lecturer on Political Economy under the auspices of the Statistical and Social Inquiry Society of Ireland (SSISI), ${ }^{4}$ and he indicated that for the

[S]ix ensuing years, it was my duty to give each year a minimum of forty public lectures in the four Irish provinces on economic subjects of contemporary interest, the lectures being analogous to the University extension lectures in Great Britain (Oldham, 1909).

The Barrington Lectures included a special course of six lectures to be delivered in Dublin. The remaining lectures would be given at selected localities in Ulster and Connacht between November and March, and they were to be delivered on the same evening of the week for not more than four successive weeks. The subjects were chosen by the local organising committee from a list of ten topics (Statistical and Social Inquiry Society of Ireland, 1897-1898). The Irish Times (28 September 1895, p. 4) reports that one of his lectures on trade unions conveyed a 'great deal of interesting information during the two hours of Mr. Oldham's discourse' to a packed and attentive audience of about 500 persons.

\section{OLDHAM AND THE DUBLIN COMMISSION}

After a lengthy campaign (discussed in, for example, Coolahan, 1981), the Irish Universities Act of 1908 established two new universities in Ireland. The old Queen's College in Belfast was raised to the status of a full university with nondenominational status but with a large Presbyterian influence. A federal National University of Ireland was established which would embrace the existing colleges at Cork and Galway and the newly formed UCD. Though legally non-denominational, the geographical location, the background of the students and the religion of the majority of the governing bodies and staff ensured that these institutions would reflect a Catholic ethos, and they were accepted and supported by the Catholic hierarchy (Coolahan, 1981). Bartlett comments (2010, p. 366) that:

$[\mathrm{N}] \mathrm{o}$ one appears to have noticed that setting up two universities [Queen's University Belfast and the National University of Ireland], each organised on a different basis, directed at different religious communities, and located in different parts of the country, might presage some form of partition.

The Irish Universities Act of 1908 provided the majority of the Irish nation with a system of education serving the burgeoning Catholic middle classes and their emerging professional cadres. The University of Dublin (TCD) was not affected by the legislation (Maxwell, 1946). 
Clarke, Ó hÓgartaigh and Ó hÓgartaigh

The most immediate of all influences shaping the new university colleges was a statutory body of ten persons, known as the Dublin Commission. This body was exclusively charged with the duty of framing statutes for the administration of the university and of its three constituent colleges at Dublin, Cork and Galway, and alone made all appointments. As part of their work the commissioners visited the universities of Liverpool, Manchester and Leeds to 'study the provision made in the universities in these cities for Technological and Commercial education' (Dublin Commission, 1909, p. 3). The Dublin Commission established thirty-six chairs and fifteen lectureships at UCD (McCartney, 1999).

A few years earlier (1901), the Rathmines School of Commerce (subsequently renamed the College of Commerce and later again a part of the Dublin Institute of Technology) had been established. Oldham was appointed its first principal. The prospectus of the school, reproduced in the Irish Times (4 September 1902), stated that its purpose was to provide technical instruction for persons of either gender who are intended for commercial pursuits and that lectures would be given only in the evenings so as to assist those who were already employed. This was in keeping with the growth of education for both men and women of the middle classes. Commercial courses were seen as particularly useful for women and Hanna SheehySkeffington, a well-known suffragist and nationalist, taught in Rathmines prior to the 1916 Rising (Luddy, 1995).

The Lord Lieutenant presented certificates and prizes to successful students of the school at the end of its first academic year (Dudley, 1905). In his speech, Lord Dudley acknowledged the uniqueness of the school in the area of commercial instruction and generally encouraged the teaching of commercial knowledge in preference to the (slower) process of accumulating personal knowledge by way of personal experience. Oldham was responsible for the early organisation of the Rathmines School, including the selection of the large staff of teachers and the mapping out of different courses of instruction (Oldham, 1909). He further pointed out that he had given regular courses of lectures at the school on commercial geography, economics, mercantile law, railway economics, trusts, 'kartels' (the German spelling was his) and combinations in modern business organisations (Oldham, 1909). Since 1898, he acted as lecturer and examiner to the Institute of Bankers in Ireland in political economy and commercial geography and history, and many of his lectures to the Institute were published in the Journal of the Institute of Bankers in Ireland (Oldham, 1909). He was their examiner in commercial geography and political economy.

In addition to accounting and commercial courses, Rathmines ran specialised courses for railway clerks, bank clerks and insurance clerks (Duff, Hegarty and Hussey, 2000). The Rathmines School of Commerce enrolled over 350 students per annum, representing a student population that the Commerce faculty in UCD would not match during its first twenty years of existence. It was the first institution of its kind to be started in Ireland.

In his capacity as principal, Charles Oldham, among others, provided important arguments to the Dublin Commissioners and drew their attention to developments in business education taking place in the United States and the continent of Europe around that time. Oldham was very much in favour of a separate Commerce 
degree rather than having a degree amalgamated with Arts, and this testimony was supported by the arguments of the representatives of the English universities. For example, the dean of the newly formed Faculty of Commerce at the University of Manchester (Professor Chapman) indicated that his university had decided to

[I]ntroduce a distinct Faculty (of Commerce) because this kind of education is only just beginning, and it will be left much freer to develop itself, and to get advice and hints from outside business people than if it is attached to the Faculty of Arts (Dublin Commission, 1909, p. 39).

Oldham advised:

I greatly prefer a distinct degree in Commerce, for if you consider you have pioneer work to do, if you create a distinct degree in Commerce, it will be a decided help towards the object aimed at. Make the qualification as high as possible, but have a distinct degree (Dublin Commission, 1909, p. 72).

In a lengthy memorandum to the Commissioners, Oldham pointed out that within the previous decade some 30 of the leading universities in America had developed commerce faculties. These included New York, Columbia, Chicago, Illinois, California, Stanford, Pennsylvania, Michigan, Wisconsin, Harvard, Yale and Vermont. He also argued that, in Great Britain, a similar situation had occurred in London, Birmingham, Manchester, Sheffield, Leeds, Liverpool and Edinburgh (Dublin Commission, 1909).

In addition, the Institute of Bankers, whose primary role was an educational one, asserted that it was 'the first body organised in Ireland for the special training and instruction of those engaged in an important branch of commerce' and argued that 'it is desirable that a fully-equipped Faculty of Commerce, analogous to the Faculties of Medicine, Law or of Engineering, should be established in connection with the National University of Ireland' (White, 1998, p. 19). The above arguments were successful, since both UCD and one of its sister colleges of the National University of Ireland, University College Cork (UCC), were founded with their own commerce faculties. However, largely for financial reasons, none was established in University College Galway (UCG) at that time.

Oldham did not support the establishment of a separate chair in Accountancy within this Faculty of Commerce and, in giving his evidence, he characterised the discipline as the ability to 'handle a balance sheet and to exercise judgement as the head of the firm on the reports which his subordinates give ... but it is not expert work, and that is where the university comes in' (Dublin Commission, 1909, p. 69).

His evidence is unequivocal:

My opinion is there is nothing of a university nature about accountancy work. It is probably the highest level of expert technical knowledge, but I see the type of men year after year ... they are experts in their own line, and require expert teaching and not university teaching; the only teaching institution that the accountancy student wants is a grinding shop to prepare him for his own examination, and that is not the function of a university .... I don't think it is right that the University should have 
Clarke, Ó hÓgartaigh and Ó hÓgartaigh

a Chair for Accountancy. I don't think there would be the work to do to warrant a Chair, but I think it very important that you should have a Lecturer in Accountancy (Dublin Commission, 1909, p. 69).

Oldham's argument against the creation of a chair of Accountancy certainly facilitated the financial viability of the hopelessly under-funded UCD. In an attempt to curb expenditure and to increase the proposed salaries of the more 'important' professorships, especially those in Medicine, the then President of the Catholic University (William Delany SJ) suggested to the Commissioners:

[T] hat there are certain Chairs the appointments to which might, for the present be postponed ${ }^{5} \ldots$ because they are not so essential, and because they may be included in the subjects of some of the other chairs ... Accountancy and Banking and Finance. We think that those subjects might be dealt with by the Professor of Commerce (Dublin Commission, 1909, p. 87).

In its report, the Commission explained:

We need not say that we regard Technological Studies as essential in the University; and were it not that there is in Dublin a College in which these studies can be pursued ... we should have felt bound to have instituted professorships in those subjects, at least in University College Dublin, although by so doing we should have rendered the resources of that College insufficient to provide for the teaching of other important subjects in University education (Dublin Commission, 1909, p. 5).

In 1909, Charles Oldham was appointed Professor of Commerce in the Faculty of Commerce at UCD. In his application he indicated that in relation to the Rathmines School:

[T] he selection of the large staff of teachers and the mapping out of the different courses of instruction, I have been charged with a sole and undivided initiative. In fact, during the eight years of its existence, nothing has been done except on my initiation and nothing has been left undone which I had suggested ... under these circumstances I may be allowed [to suggest that] the Rathmines School of Commerce as being the best objective evidence of my own qualifications to the Chair of Commerce in the University College, Dublin (Oldham, 1909).

Around that time Oldham moved from his Leeson Street residence to 55 Terenure Road (Rathmines and Rathgar district) where he lived with his wife, Katherina (commonly known as Kathë), then aged 49 years. ${ }^{6}$ Bridget Kelly, who also lived at this address, is described as a 'general domestic servant' (Census, 1911).

At this time, therefore, Oldham moved his intellectual and geographical locale. The man who was a prime mover in the literary and political life of Dublin in the latter decades of the nineteenth century became one of the primogenitors of thirdlevel commerce education two decades later. 
'A Distinct Degree in Commerce'

\section{OLDHAM AND COMMERCE EDUCATION AT UCD}

UCD was founded by the Irish Universities Act 1908 and began life as a teaching institution on 2 November 1909 when it enrolled its first students (McCartney, 1999). Overall student numbers in this new university were small and did not exceed 1,000 during the first five years (in contrast with 350 business students alone enrolling in the Rathmines School each year). In the first academic year (1909/1910), there were a total of 530 students in the university, of which in excess of 90 per cent were male. As Williams (1954, p. 166) notes, in its first year UCD was 'a small college by modern standards; what had been granted was a modest provision for a limited future rather than an expansive or over-generous financial contribution.'

The statutes of the Irish Universities Act 1908 (Chapters XI and XVI) provided for the establishment of a commerce faculty at UCD. ${ }^{7}$ The faculty was to have a professor of Commerce, with an annual salary of $£ 400$, and lectureships in accountancy, and banking and finance, with annual salaries of $£ 150$ and $£ 100$ respectively. The positions were advertised in, for example, the Irish Times. The closing date for completed applications was 31 August 1909 and appointments were to be made in October (Irish Times, 5 August 1909, and earlier dates). In addition, provision was made for two additional professorships, namely in the national economics of Ireland and political economy, both on annual salaries of $£ 500$. The offices were tenable for seven years and the holders were eligible for re-appointment.

Having been a prominent contributor to the Dublin Commission's work on the establishment of third level education, Oldham was appointed by the Dublin Commission as Professor of Commerce at UCD on Saturday 23 October 1909. The President of University College Dublin's Report (1925-1926, p. 27) subsequently noted that he had been a prominent worker in economic studies and had much practical experience in the development of schools (sic) of commerce. Oldham was honest enough to admit that his application in 1901 for the chair in Commerce then being established in the new University of Birmingham (England's first Faculty of Commerce) had been unsuccessful (Oldham, 1909).

The first meeting of the UCD Faculty of Commerce was held on 31 March 1910. The meeting was called for 2 p.m. and at 2.25 p.m. Professor Finlay was proposed as chairman. In addition to Professor Finlay, this first meeting was attended by Professors Oldham, Kettle, Cadic and Murnaghan, and Mary Macken, all from UCD; representatives from the sister colleges established under the 1908 Irish Universities Act (UCC and UCG) also attended. The minutes note that on the motion proposed by Finlay and seconded by Macken, it was agreed that Oldham be chosen as dean of the Faculty of Commerce in UCD (Faculty of Commerce, minute book, minutes for 31 March 1910).

The main item for discussion at this first meeting was a comparison of the courses for study in both UCD and UCC. Some minor differences were noted but no changes were recommended to either curriculum. The meeting lasted just over 30 minutes. The second Faculty of Commerce meeting was held on 1 June 1910 and the main item discussed was the proposed certificate in Commerce at UCC. After much discussion it was agreed that this certificate in Commerce would be delivered 
Clarke, Ó hÓgartaigh and Ó hÓgartaigh

in UCC; UCD did not express an interest in such a programme. A third meeting followed on 21 November 1912, at which Oldham was reappointed as dean - a post which he retained until his sudden death in 1926. A handwritten note in the faculty minute book, dated 14 June 1927, reads 'The minute book containing the minutes of meetings prior to June 1927 is not available. It was probably in the possession of the late Professor Oldham' (Faculty of Commerce, minute book, p. 20). The UCD Calendar (1910-1911) for that period indicates that the Faculty of Commerce consisted of Oldham (Professor of Commerce), Kettle (Professor of National Economics), Finlay (Professor of Political Economy) and the lecturers in both accountancy, and banking and finance (both vacant), as well as various professors and lecturers in law, history and languages based in other faculties.

Oldham was appointed Professor of National Economics on the death of the incumbent, Professor Tom Kettle, who was killed at the Somme in 1916. Two years earlier, Oldham had been appointed to give lectures on the national economics of Ireland in locum tenens for Professor Kettle during the latter's absence on active service with the Irish Brigade (Irish Times, 28 November 1914).

Oldham was appointed as temporary Professor of National Economics and he was to be paid one guinea per lecture and $£ 10$ for examination work, the fees to be deducted from Professor Kettle's salary (UCD Governing Body, 22 December 1914). Meenan (1980) subsequently informs us that in 1917 the college proceeded to fill the vacancy and advertised it in the usual way. The chair went, after a closely fought contest, to Oldham. (In turn, Oldham's chair was filled by George O'Brien a former UCD student but an external candidate - who would serve as dean of the Commerce Faculty from 1951 to 1961.)

As far as can be ascertained, Professor Oldham delivered the first lectures in the Faculty of Commerce, commencing on 11 January 1910, dealing with the geographical basis of international commerce. These were delivered on Tuesday and Thursday afternoons at 4.30 p.m. in the Physics Theatre in Earlsfort Terrace in the Hilary and Trinity terms. The minutes of the UCD Governing Body show that it was agreed that these lectures would be free to Commerce students and that others were to pay £1-1-0 (UCD Governing Body, 4 January 1910), and subsequently it was agreed to grant the Professor of Commerce $£ 10$ to purchase photographic slides for these lectures (UCD Governing Body, 22 March 1910).

The UCD President's report (President of University College Dublin, 1909-1910) for the first academic session of the university indicated that five (male) students attended Commerce lectures in this first session, and that this required expenditure for class materials of $£ 27.18 .9$ out of a total university spend of $£ 715.12 .7$ under this heading. The National University Handbook (National University of Ireland, 1932, p. 101) acknowledges that 'the first organisation of the Courses in Commerce was carried out with great care by the late Professor Oldham'. The following year (1910/1911) it is noted that Oldham delivered a special course of lectures on the subject of national finance during Trinity term; these lectures 'were attended by students of the BA and MA classes in economics as well as by other voluntary students' (President of University College Dublin, 1910-1911, p. 10). It is likely that these are the same series of eight Saturday afternoon lectures reported in the Irish 
Times as attracting 'a very large audience', which filled the Physics Theatre (Irish Times, 8 May 1911).

The first B.Comm. students began their studies in the autumn of 1911 and sat their first Commerce examination in the summer of 1912. Only two examination candidates were listed. Lilian Deignan was awarded 'honours' and Thomas Fitzpatrick a 'pass'. It was reported that the lectures in Commerce and in Banking and Finance were largely attended by non-university students for whom special arrangements were made, and Oldham's special course continued (President of University College Dublin, 1911-1912). At the same time, one hundred students sat their first Arts exams, nineteen sat their first Science exams and seven sat their first Law examinations (University College Dublin Report, 1911-1912). Both aforementioned Commerce students in 1911-1912 completed their B. Comm. studies in 1913-1914 with 'pass' degrees.

C.S. (Todd) Andrews, an early graduate of UCD who was subsequently managing director and chairman of a number of semi-state organisations, recalls (1982, p. 39) that the 'Commerce degree at that time had the lowest standing in Academe, below even the BA pass degree in Trinity College which had an exceptionally poor reputation'. Another student, who was to become a leader of Fine Gael, an independent TD and Minister for Agriculture, James Dillon, became so convinced of the uselessness of the (UCD) Commerce degree that he withdrew from university without ever sitting for his degree (Manning, 1999).

Andrews (1982, p. 40) described Oldham as follows:

\begin{abstract}
In appearance Oldham was a wiry old man with a rugged face and closely cropped white hair with which he was well endowed even in his late sixties. He had an uncommonly loud, harsh voice which had the effect of unintentionally intimidating his classes. His accent was unmistakably Dublin but of a kind particular to welleducated Protestants and to Catholics of second generation affluence.... I recall a lecture in which he lamented the stoppage of emigration caused by the Great War. The events of 1916 and after were caused, in his view, by this curb on population movements in that it forced the young men, for want of something better to do, to take to the barricades. Feeling this to be a rather simplistic explanation of the rise of the Volunteer movement I stood up in class and said so. Oldham was neither abashed nor annoyed by my interruption. He heard me out and proceeded in his raucous voice and painfully humourless manner to defend his argument with a wealth of statistics.
\end{abstract}

Under Oldham's deanship, the number of commerce degree awards, and registered students, gradually increased, as reported in Table 1, but the numbers were always going to be small in a university whose arts and medical faculties were the biggest.

While the number of commerce degrees awarded might appear to be small by today's standards, in terms of student numbers, the Faculty of Commerce was the most successful in the (then) United Kingdom, surpassing Birmingham, Belfast and Cork (National University of Ireland, 1919).

Candidates for the first Commerce examination had to present themselves in five subjects as set out in Table 2. 
Clarke, Ó hÓgartaigh and Ó hÓgartaigh

TABLE I: COMMERCE AND OTHER DEGREES AWARDED AT UCD, $1913 / 1914-1925 / 1926$

\begin{tabular}{lccc}
\hline & $\begin{array}{c}\text { (a) B.Comm. } \\
\text { Degrees }\end{array}$ & (b) Total Degrees & $\begin{array}{c}\text { Percentage of Total } \\
\text { Degrees that are } \\
\text { B.Comm. Degrees }\end{array}$ \\
$1913 / 1914$ & 2 & 191 & $1 \%$ \\
$1914 / 1915$ & 3 & 198 & $2 \%$ \\
$1915 / 1916$ & 4 & 171 & $2 \%$ \\
$1916 / 1917$ & 7 & 187 & $4 \%$ \\
$1917 / 1918$ & 10 & 181 & $6 \%$ \\
$1918 / 1919$ & 8 & 190 & $4 \%$ \\
$1919 / 1920$ & 10 & 217 & $5 \%$ \\
$1920 / 1921$ & 14 & 265 & $5 \%$ \\
$1921 / 1922$ & 17 & 268 & $6 \%$ \\
$1922 / 1923$ & 14 & 253 & $6 \%$ \\
$1923 / 1924$ & 21 & 286 & $7 \%$ \\
$1924 / 1925$ & 27 & 360 & $8 \%$ \\
$1925 / 1926$ & 40 & 312 & $13 \%$ \\
\hline
\end{tabular}

Source: Compiled from President of University College Dublin (1935-1936)

The second and third year courses consisted of additional courses in Commerce, Accountancy, Political Economy, Law and Languages. This range of subjects was very similar to those subjects on offer in the recently established Faculty of Commerce in the University of Manchester (Dublin Commission, 1909, p. 27). A volume of handwritten lecture notes (about 200 pages) by Oldham for a course in the B.Comm. degree in UCD on the national economics of Ireland is available in the UCD archives (Oldham, notes undated). These notes focus primarily on, for example, Irish population and emigration figures, including statistics relating to the official censuses of 1821 to 1911, and figures relating to agriculture and industry; imports and exports; international comparisons; topography; local land division; and administration and jurisdiction. Included are occasional examination papers for courses which he taught in UCD. These papers were presented to the Faculty of Commerce around 1933 by his widow, Kathë Oldham (Faculty of Commerce, minute book, minutes of 16 May 1933).

TABLE 2: PAPERS IN THE FIRST COMMERCE EXAMINATION (UCD, $1910 / 1911)$

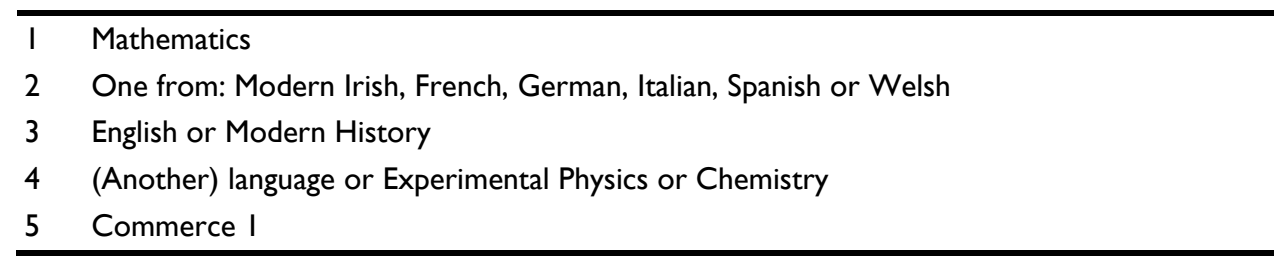

Source: Compiled from UCD Calendar (1910-1911) 
Oldham continued as an active member of the SSISI for nearly forty years. It was through the society that he became well-known as an economist (Black, 1947). Daly (1997) argues that some of Oldham's early papers to the society on Irish industrial history deserve to be ranked among the classical revisionist texts. However, it should be noted that there were revisionist writers long before Oldham and he is part of that distinguished tradition.

In all, he was the author of some twenty papers read before the society, which using today's terminology would include a remarkably wide range of topics in which he was especially interested, including national economics; economic history; education; international business and trade; population and demography; and statistics (see Appendix 1). In addition to presenting papers at regular intervals, Oldham acted as honorary secretary of the SSISI from 1895 to 1908. Appointed a Barrington lecturer in 1895, he was re-appointed annually until 1901 (Millin, 1920).

His contribution to the society is summarised in the following terms (Black, 1947, pp. 83-84):

During the period 1890-1925 the Statistical Society had scarcely any more active member or frequent contributor than C.H. Oldham [and his] thirty-nine years of membership included those in which the Society's fortunes were at their lowest ebb, and he was instrumental in carrying it on and aiding it towards new development.

He was also a regular contributor to The Economist and other periodicals and societies (Black, 1947). One noteworthy publication not previously mentioned is The Public Finances of Ireland (Oldham, 1911). This publication coincided with the impending Home Rule Bill and was quoted extensively by Dunraven (1912), and provided solid evidence that under the Act of Union, Ireland was burdened with an unfair share of UK taxation. This was an important consideration in fuelling the nationalistic spirit in Ireland around that time.

Oldham died suddenly on 20 February 1926 at his residence in 5 Victoria Terrace, Rathgar (see Death Certificate, Reg. No. 2711111). The Irish Times (24 February 1926) reported on his funeral, at which a message of sympathy was read from William T. Cosgrave, the President of the Executive Council (of the Irish Free State). The attendance included many of his UCD professorial colleagues, including the UCD President, Denis Coffey, and academic colleagues from other Irish universities. He was survived by his wife, but had no children. The service at the grave was conducted by the Rev. John Murray, Oldham's life-long friend who had married Charles and Kathë in London on 11 August 1902 (Irish Times, 16 August 1902). In that sense, Oldham's passing was symbolic of his life: he had passed from bring a political figure of some significance in late nineteenth-century Ireland to a personage of largely academic prominence and marginal political involvement. He was also emblematic of an élite, an 'urban intelligentsia' (Goldring, 1993, p. 18) of pre-independence Ireland who were a more faded part of the weave of the newly emergent Irish Free State (Foster, 1988; Goldring, 1993; Fitzpatrick, 1998).

It would be remiss not to include reference to both his wife and his sisters in a paper on Charles Oldham. In 1908, his wife, Kathë, became president of the Irish Women's Franchise League, a suffrage movement at the start of the twentieth 
Clarke, Ó hÓgartaigh and Ó hÓgartaigh

century involved with Irish nationalism and the cultural revival (Cousins and Cousins, 1995). Kathë died on 27 November 1946, aged 80 years, and was buried with her husband in Deansgrange cemetery in a private ceremony (Irish Times, 29 November 1946).

His sister Alice Oldham, who was appointed to the teaching staff of Alexandra College (Dublin) in 1886, became the leader of the campaign for the admission of women to TCD and was secretary of the Central Association of Irish Schoolmistresses from its foundation in 1882 until 1905. In this capacity, she conducted a continuous correspondence with the board of TCD, arguing the case for the admission of women to TCD, but the board decided that it could not admit women on to a residential male campus and stated that the charter and statutes did not permit it to do so. Eventually, in 1904, the board finally conceded, but women were prohibited from residing in the college and were expected to leave the campus by 6 p.m. each evening (Harford, 2008). Alice Oldham's struggle for the admission of women went largely unacknowledged until recent years (Parkes, 2004). Another sister, Edith Oldham, was an important figure in music in Dublin in the late nineteenth century and into the twentieth century and was the first (joint) honorary secretary of the Feis Ceoil association and a key member of staff of the Royal Irish Academy of Music for nearly fifty years (O'Connor, 2006).

\section{SUMMARY AND CONCLUSION}

On Oldham's death, an obituary in the Irish Times (22 February 1926) reported that:

Mr. Oldham was respected by all for his integrity and sincerity, and even his frank expression of his opinions brought him no lasting enmities, while students regarded him with affection. For one whose life work was devoted to an abstract branch of knowledge, his general culture was wide, and it found expression in that generosity which was one of his most noted qualities.

His UCD colleague Professor George O'Brien stated that the study of political economy in Ireland had suffered a heavy loss by the death of Professor Oldham, whose writings, which were mostly on Irish subjects, would, if collected, form a large volume. The UCD President's report stated that 'his personal worth, his great success as an investigator and teacher, and his never failing interest in all that concerned the college and its members won him the abiding regard of his colleagues and his pupils' (University College Dublin Report 1925-1926, pp. 4-5). One of his colleagues at the Contemporary Club, Harry Nicholls (1965b), wrote that Oldham 'had one of the most massive intellects with which I have ever come in contact [and] he was incapable of intellectual dishonesty. To some, he appeared arrogant but the judgement was false. Those who knew him best know how modest he really was.'

This paper has provided a biographical background on Professor Charles Oldham. Further research will assess his 'agential power' (Lloyd, 1993, p .43) in this important period in Irish history and will position him in a historical context. He had an extraordinary background, which included a number of 'firsts', in terms of 
academic achievements and cultural contributions. His achievements are not only worthy of consideration in their own right but also as signals of a passing age, a passing of power from a largely Protestant Ireland, a Home Rule Ireland to a Catholic Free State.

After a political life in the Home Rule movement of the late nineteenth century, Oldham became part of the intellectual rather than political fabric of the newly independent state. In effect, he belonged to a moderate Protestant establishment which, in the context of the War of Independence, was replaced in the vanguard of the leadership of a newly independent Ireland by a more thrusting republican Catholic élite in a 'putsch of the middle classes' (O'Faoláin, 1943, p. 181). Like many of his generation and class, Oldham found a new intellectual identity in the structures of the newly emergent Free State. The political Oldham of Home Rule and the Liberal Party became the academic Oldham of commerce and UCD.

\section{ACKNOWLEDGEMENTS}

The authors acknowledge the invaluable assistance of Felix Larkin and Liam Smyth in the preparation of this paper.

\section{APPENDIX 1}

\section{PAPERS AND ADDRESSES OF CHARLES OLDHAM TO THE STATISTICAL AND SOCIAL INQUIRY SOCIETY OF IRELAND}

I. The Fluctuating Character of Modern Employment, Vol. X (I895-1896)

2. Economic Development in Ireland, Vol. X (I899-1900)

3. The Bearing on Industry of the Impending Changes in Irish Education, Vol. XI (1900-190I)

4. Technical Education for Commerce, Vol. XI (I90I-1902)

5. Kartels and Syndicates in German Industry, Vol. XI (1903-1904)

6. The Economics of 'Industrial Revival' in Ireland, Vol. XII (1907-1908)

7. The Education of American Business Men, Vol. XII (1909-1910)

8. The History of Belfast Shipbuilding, Vol. XI (1910-1911)

9. The Incidence of Emigration on Town and Country Life in Ireland, Vol. XIII (I9/3-19/4)

10. The Economic Interests Involved in the Present War, Vol. XIII (1914-1915)

II. British Finance of the War, Vol. XIII (1915-1916)

12. Industrial Ireland under Free Trade, Vol. XIII (1915-1917)

13. Changes in Irish Exports during Twelve Years, Vol. XIII (1917-1919)

14. Changes in Export Industries of Ireland: 1904-1916, Vol. XIII (1917-1919)

15. The Public Finances of Ireland, Vol. XIV (1919-1920)

16. The Development of Tillage in Ireland during the World War, Vol. XIV (1920-1923)

17. Some Perplexities in Regard to the Agricultural Statistics of Ireland, Vol. XIV (1923-1925)

18. The Interpretation of Irish Statistics, Vol. XIV (1923-1925)

19. The Trade Statistics of the Irish Free State in 1924, Vol. XIV (1923-1925)

20. Reform of the Irish Census of Population, Vol. XIV (1925-1927)

${ }^{*}$ Dates refer to publication years in the Journal of the Statistical and Social Inquiry Society of Ireland. Source: Hayes, 1970, pp. 261-262. 
Clarke, Ó hÓgartaigh and Ó hÓgartaigh

\section{NOTES}

I. Ellen O'Leary in a letter to W.B.Yeats, 12 January 1889 in Yeats (1972, p. I27).

2. See <http://www.dit.ie/about/about-dit/history/>.

3. Oldham supported free trade principles, in contrast to Griffith, who drew on List's infant industry argument to advocate a protectionist policy (Lee, 1989; Johnson, 2005).

4. Since its foundation in 1847 , the Society has analysed the major changes that have taken place in population, employment, legal and administrative systems and social services, and its journal provides an insight into the thoughts of a professional and intellectual elite on some of the most important aspects of Irish society.

5. 'Postponement' lasted longer than first anticipated. However, an internal report (National University of Ireland, 1919, p. I5) strongly recommended the appointment of a part-time professor of Accountancy who 'should be a qualified accountant in active practice of his profession [and this recommendation] is to make obvious the indisputable fact that Accountancy requires a very considerable development in the Faculty of Commerce at Dublin [and] that much more time, and more specialised and advanced teaching, for Accountancy should be supplied immediately'. Eventually, a part-time chair in Accountancy was created in UCD and filled by Gerard O'Brien in 1962 - the only applicant for the position (Faculty of Commerce minutes, I I December 1962). Gerard O'Brien, a partner in the prestigious accountancy firm of Craig Gardner, had been appointed as a lecturer in Accountancy in UCD in 1935 on the death of the incumbent, Donal O'Connor. On O'Brien's retirement, the chair was converted into a full-time one and filled by the late Professor Desmond Hally, who was previously appointed as a college lecturer on I February 1965 (Faculty of Commerce minutes, 22 June 1964). The present incumbent is Ciarán Ó hÓgartaigh, who (in 2008) succeeded Professor Francis O'Brien, who had taken over the position from Professor Hally in 1993.

6. Around the time of his appointment to the Rathmines School of Commerce, Oldham travelled overseas and his mother writes (Oldham, A., 30 July 1884) that on one of their trips to Europe Oldham met 'two charming German ladies' with whom he travelled for four days (Oldham,A., 19 March 1885). It is anticipated that one of these 'charming ladies' was Oldham's future wife, Kathë.

7. A School of Commerce was established in TCD in 1925, primarily as a result of pressure from the Protestant middle classes, who wanted their sons to be given some 'polish and the chance of making the right kind of friend'; however 'it did not add much to the lustre of the college, but at least it induced a few commercially minded fathers to give their sons a university education without feeling that they were completely wasting their time' (McDowell andWebb, 1982, p. 449).

\section{REFERENCES}

Anderson-Gough, F. (2008). Accounting Education, in R.H. Edwards and S. Walker (eds.), Routledge Companion to Accounting History, pp. 297-316, Abingdon: Routledge.

Andrews, C.S. (1982). Man of No Property, Dublin: Mercier Press.

Bartlett, T. (2010). Ireland: A History, Cambridge: Cambridge University Press.

Black, R. (1947). The Statistical and Social Inquiry Society of Ireland, Centenary Volume, Dublin: Eason and Son.

Census (1911). Census of Population, National Archives, <http://www.census.national archives.ie/search/>.

Chaudhry, Y. (2001). Yeats, the Irish Literary Revival and the Politics of Print, Cork: Cork University Press.

Clarke, P. (2005). The Story of Bernard F. Shields: The First Professor of Accountancy in the UK, Accounting History, Vol. 10, No. 2, pp. 103-123. 
'A Distinct Degree in Commerce'

Coolahan, J. (1981). Irish Education: Its History and Structure, Dublin: Institute of Public Administration.

Cousins, J. and Cousins, M. (1995). The Beginnings of Militant Suffragism in Ireland, in M. Luddy (ed.), Women in Ireland, 1800-1918: A Documentary History, Cork: Cork University Press (originally published in 1950).

Daly, D. (1974). The Young Douglas Hyde: The Dawn of the Irish Revolution and Renaissance 18741893, Dublin: Irish University Press.

Daly, M. (1997). The Spirit of Inquiry: The Statistical and Social Inquiry Society of Ireland 18471997, Dublin: Institute of Public Administration.

Davitt, M. (1885). Irish Conservatism and Its Outlooks, Dublin University Review, Vol. 1, No. 8, pp. 93-108.

Dublin Commission (1909). Report to Accompany Statutes Made by the Dublin Commissioners Appointed under the Irish Universities Act, 1908, Cd. 4726, Dublin: Stationery Office.

Dublin University Review (1885). Editorial Notes, Dublin University Review, Vol. 1, No. 6.

Dudley, Earl of (1905). Milestones on an Irish Journey: Some Speeches Delivered by His Excellency the Earl of Dudley during his Vice-Royalty in Ireland, Dublin: Alex Thom.

Duff, T., Hegarty, J. and Hussey, M. (2000). The Story of the Dublin Institute of Technology, Dublin: Blackhall Publishing.

Dunraven, Earl of (1912) The Finances of Ireland: Before the Union and After, London: John Murray.

Faculty of Commerce (undated). Minute Book of the Faculty of Commerce, National University of Ireland (held in UCD Archives).

Ferguson, C. (2009). Private e-mails to P. Clarke from Ms. Catherine Ferguson, New Zealand, who is a lineal descendant of the late Charles Hubert Oldham.

Ferguson, K. (2005). King's Inns Barristers 1968-2004, Dublin: The Honorable Society of King's Inns in association with the Irish Legal History Society.

Fitzpatrick, D. (1998). The Two Irelands, 1912-1939, Oxford: Oxford University Press.

Foster, R.F. (1988). Modern Ireland: 1600-1972, London: Penguin.

Foster, R.F. (1997). W.B. Yeats: A Life, Oxford: Oxford University Press.

Goldring, M. (1993). Pleasant the Scholar's Life: Irish Intellectuals and the Construction of the Nation State, London: Serif.

Governing Body (as dated). Minutes of the UCD Governing Body (Minute Book, held in UCD Archives).

Harford, J. (2008). The Opening of University Education to Women in Ireland, Dublin: Irish Academic Press.

Hayes, R.J. (ed.) (1970). Sources for the History of Irish Civilization: Articles in Irish Periodicals, Boston, MA: G.K. Hall.

Hickey, D. and Doherty, J. (1980). A Dictionary of Irish History since 1800, Dublin: Gill and Macmillan.

Irish Law Times (1890). Irish Law Times and Solicitors' Journal, Vol. XXIV.

Irish Times, Dublin (various, as dated).

Irish Universities Act (1908). 8 Edw, c 38, 1 August 1908.

Johnson, R. (2005). Century of Endeavour: A Biographical and Autobiographical View of the Twentieth Century in Ireland, Dublin: Lilliput Press.

King's Inns (undated). Personal file for Charles Hubert Oldham, Dublin: King's Inns.

Lee, J. (1989). Ireland 1912-1985: Politics and Society, Cambridge: Cambridge University Press.

Lloyd, C. (1993). The Structures of History, Oxford: Oxford University Press.

Luddy, M. (1995). Hanna Sheehy Skeffington, Dublin: Historical Association of Ireland.

Lysaght, C. (2005). James Meenan, in J. Meenan (ed.), Centenary History of the Literary and Historical Society of University College Dublin 1855-1955, Dublin: A. \& A. Farmar.

Manning, M. (1999). James Dillon: A Biography, Dublin: Wolfhound Press. 
Clarke, Ó hÓgartaigh and Ó hÓgartaigh

Maxwell, C. (1946). A History of Trinity College Dublin: 1591-1892, Dublin: Trinity College Dublin.

McCartney, D. (1999). UCD: A National Idea, Dublin: Gill and Macmillan.

McDowell, R. and Webb, D. (1982). Trinity College Dublin: 1592-1952, Cambridge: Cambridge University Press.

McGee, O. (2009). Oldham, Charles Hubert, in J. McGuire and J. Quinn (eds.), Dictionary of Irish Biography, pp. 629-630, Cambridge: Cambridge University Press.

Meenan, J. (1980). George O'Brien: A Biographical Memoir, Dublin: Gill and Macmillan.

Millin, S.S. (1920). Historical Memoirs by S. Shannon Millin, Dublin: The Statistical and Social Inquiry Society of Ireland.

National University of Ireland (1919). Faculty of Commerce: A Report on the Permanent Needs of this Faculty and Its Improved Equipment, Dublin: National University of Ireland.

National University of Ireland (1932). The National University Handbook, 1908-1932, Dublin: Three Candles.

Nicholls, H. (1965a). Memories of the Contemporary Club, 1, Irish Times, 20 December.

Nicholls, H. (1965b). Memories of the Contemporary Club, 2, Irish Times, 21 December.

O'Connor, J. (2006). Edith Oldham: Her Involvement in Music in the Late Nineteenth century, paper presented at the SMI Conference, Mary Immaculate College, Limerick, 5-7 May.

O'Faoláin, S. (1943). The Stuffed-Shirts, The Bell, Vol. 6, No. 3, pp. 181-183.

Oldham, A. (as dated). Letters from Mrs Anne Oldham to her daughter Edith Oldham (18801888), Sir George Grove collection, London: Royal College of Music, MS 6863.

Oldham, C. (notes undated). Notebook of Charles Oldham (1860-1926), UCD Archives (Reference code IE UCDA LA40).

Oldham, C. (1909). File containing the application of Charles Hubert Oldham, candidate for the Professorship of Commerce, University College Dublin (unpublished), Dublin: National University of Ireland.

Oldham, C. (1911). The Public Finances of Ireland, Dublin: C. Oldham/Dollard Printers.

Parkes, S. (ed.) (2004). A Danger to the Men? A History of Women in Trinity College Dublin, 19042004, Dublin: Lilliput Press.

President of University College Dublin (1935-1936). Report of the President of University College Dublin for the Session 1935-36, Dublin: Browne and Nolan.

President of University College Dublin (1925-1926). Report of the President of University College Dublin for the session 1925-26, Dublin: Browne and Nolan.

President of University College Dublin (1911-1912). Report of the President of University College Dublin for the Session 1911-12, Dublin: Browne and Nolan.

President of University College Dublin (1909-1910). Report of the President of University College Dublin for the Session 1909-10, Dublin: Browne and Nolan.

Statistical and Social Inquiry Society of Ireland (1897-1898). Notice on Barrington Lectures on Political Economy, 1897-1898.

Thom's Directory (1884). Thom's Official Directory of the United Kingdom of Great Britain and Ireland for the Year 1884, Dublin: Alex. Thom and Co.

Thom's Directory (1894). Thom's Official Directory of the United Kingdom of Great Britain and Ireland for the Year 1894, Dublin: Alex. Thom and Co.

Thom's Directory (1897). Thom's Official Directory of the United Kingdom of Great Britain and Ireland for the Year 1897, Dublin: Alex. Thom and Co.

Trinity College (1951). Record Volume, Dublin: Hodges, Figgis \& Co.

University College Dublin Calendar, (1910-1911). Calendar for the Session 1910-11, Dublin: Browne and Nolan.

White, J. (1998). A Century of Banking, Dublin: The Institute of Bankers. 
'A Distinct Degree in Commerce'

Williams, T.D. (1954). The College and the Nation, in M. Tierney (ed.), Struggle with Fortune: A Miscellany for the Centenary of The Catholic University of Ireland 1852-1954, Dublin: Browne and Nolan.

Yeats, W.B. (1972). Memoirs (of) W.B. Yeats: Autobiography and First Draft Journal, D. Donoghue (ed.), London: Macmillan. 